\title{
Accelerating Sustainable Energy Development through Industry 4.0 Technologies
}

Mohammed Ali Berawi ${ }^{1 *}$, Nyoman Suwartha ${ }^{1}$, Isti Surjandari², T. Yuri M. Zagloel2, Muhamad Asvial ${ }^{3}$, Ruki Harwahyu3 ${ }^{3}$, Muhammad Suryanegara3 ${ }^{3}$ Eko Adhi Setiawan³, Imam Jauhari Maknun ${ }^{1}$, Eny Kusrini' ${ }^{4}$, Sutrasno Kartohardjono ${ }^{4}$, Nofrijon Sofyan ${ }^{5}$, Akhmad Herman Yuwono ${ }^{5}$, Sri Harjanto ${ }^{5}$, Nandy Putra6, Muhammad Arif Budiyanto6, Yudan Whulanza6

${ }^{1}$ Department of Civil Engineering, Faculty of Engineering, Universitas Indonesia, Kampus UI Depok, Depok 16424, Indonesia

2Department of Industrial Engineering, Faculty of Engineering, Universitas Indonesia, Kampus UI Depok, Depok 16424, Indonesia

${ }^{3}$ Department of Electrical Engineering, Faculty of Engineering, Universitas Indonesia, Kampus UI Depok, Depok 16424, Indonesia

${ }^{4}$ Department of Chemical Engineering, Faculty of Engineering, Universitas Indonesia, Kampus UI Depok, Depok 16424, Indonesia

${ }^{5}$ Department of Metallurgical and Material Engineering, Faculty of Engineering, Universitas Indonesia, Kampus UI Depok, Depok 16424, Indonesia

${ }^{6}$ Department of Mechanical Engineering, Faculty of Engineering, Universitas Indonesia, Kampus UI Depok, Depok 16424, Indonesia

The technologies of the fourth industrial revolution (Industry 4.0) are already being used in the energy sector to transform the business processes of the industry. Energy management systems based on emerging technologies, including artificial intelligence (AI), internet of things (IoT), big data, blockchain, and machine learning (ML), have been used to support industry players in analyzing the energy market, improving the supply-demand chain, real-time monitoring, and generating more options for using alternative sources of energy, such as storage devices, fuel cells, and intelligent energy performance.

The optimization of the energy industry can be achieved through energy production and distribution efficiency by the digitization of manufacturing processes and service delivery. Optimized energy pricing and capital resources, predictive operation and maintenance plans, efficiency of energy usage, and further maximizing asset lifetime and usage are among the solutions produced from the technologies of Industry 4.0.

These technologies are set to transform the energy industry to being more sustainable. This transformation has happened through the provision of integrated information in both planning and operational processes. Industry 4.0 technologies contribute to the efficiency and effectiveness of energy product life-cycles and value chains, therefore impacting business strategies to produce better energy management systems.

Smart energy ecosystems that employ cyber-physical systems enhance all production

${ }^{*}$ Corresponding author's email: maberawi@eng.ui.ac.id, Tel.: +62-21-7270029, Fax: +62-21-7270028 doi: 10.14716/ijtech.v11i8.4627 
and consumption energy chain processes. Smart applications in energy production and usage consumption processes can be used efficiently in managing and optimizing energy, such as by storing energy on demand or reducing consumption.

Utilizing Industry 4.0 technologies to create a sustainable energy industry enables a decentralized energy system in which energy can be effectively produced, managed, and controlled from local resources. Furthermore, the technologies also enable data capture and analysis to improve energy performance. As digital energy is being developed and increasingly decentralized, renewable energy is now a more attractive option for creating sustainable development. The technologies are capable of integrating different energy sources to respond to an increasingly demanding and distributed market by providing sustainable and efficient resources.

\section{Advancing Science and Technological Performance}

This special issue is dedicated to discussing the progress of energy management systems and digital technologies through promoting collaboration between stakeholders to provide innovative solutions. The papers are selected from the SPBPU IDE-2020 and SES2020 conferences in Russia.

In this edition, we are pleased to present 17 selected papers dedicated to advancing science and technology by strengthening scientific research and improving technological performance.

The first paper, written by E. Koroleva, M. Baggieri, and S. Nalwanga, examines the association between environmental, social, and governance factors and company performance. The authors find that the performance of companies that comply with environmental, social, and governance principles is significantly higher compared to other companies, with the governance factor being particularly strongly related to company performance. They argue that in the industrial sectors in which the examined companies are involved, significant governance, environmental, and social factors emerge and lead to better profits.

The next paper, written by B. Tatiana and K. Mikhail, examines the relationship between innovative strategies recommended to companies and the stage in the industry life cycle, together with the specifics of territorial and regional factors. The authors argue that the choice to use classical competition tools or innovative ones, including radical strategic approaches, depends on the specifics of industry and regional factors.

The third paper, written by A. Zaytsev, D. Rodionov, N. Dmitriev, and S. Ilchenko, develops a methodology for assessing intellectual capital from the perspective of its rental income performance through a comparative analysis of the proposed method and the classical ways used to assess the intellectual capital of an enterprise. The authors argue that assessing the intellectualization level of the enterprise makes it possible to define the strategic perspectives of its long-term development.

The fourth paper, written by L. Tashenova, A. Babkin, D. Mamrayeva, and I. Babkin, develops a method for assessing the digital potential of backbone innovatively active industrial clusters, based on the methods identified and on existing research approaches for evaluating the innovation potential of industrial clusters. The authors argue that the method developed for evaluating the digital potential of a backbone innovatively active industrial cluster successfully works on the example cluster.

The fifth paper, written by E. Zhogova, O. Zaborovskaia, and O.S. Nadezhina, examines the priority sectors (industry) for the development of the Leningrad region by ranking them according to their degree of importance. The authors argue that the effectiveness of 
industrial sectors and the number of people employed are important for the economic feasibility analysis and can insure the development of the most efficient industrial policy.

The next paper, written by N. Rozhentcova, A. Galyautdinova, R. Khayaliev, A.V. Udaratin and S. Ilyashenko, develops the monitoring, control, and diagnostics systems for power transformer equipment into an automated control system using a QR code. The authors argue that the automation of the power transformer diagnostic system will reduce the time for repair work and restore the necessary protective modes, as well as allowing the rational use of both material resources and maintenance personnel.

The seventh paper, written by M.V. Borodin, R.P. Belikov, N.E. Lysenko, I.V. Shabanov, and A.R. Safin, describes the development of a universal switch to reduce the time needed for resistance measuring of the grounding device of $110 \mathrm{kV}$ overhead power line supports using the pulse method. The authors argue that the developed universal switch is effective and encourage its further development.

The eighth paper, written by A. Semenov, I. Yakushev, Y. Kharitonov, V. Shevchuk, E. Gracheva, and S. Ilyashenko, presents a calculation in the construction of load diagrams and static characteristics of a multi-motor electric drive system for a mining roadheader, using the methods of equivalent forces and reduced moments, and computer modeling. The authors argue that the results can be useful for further computer simulation of the operation of electric drive systems of a mining roadheader and the power supply system of a mining site.

The next paper, written by L.N. Goncharova, develops an approach to providing a comprehensive high-quality health care service to people with dementia (CSPD), including the services of accommodation, care, medical treatment, and leisure in kind at a level guaranteed by the Russian state. The authors argue that if citizens with an above average income allocate $1 \%$ to a personal CSPD fund, they could receive this service-in-kind in case of disease under the guarantees of the state.

The tenth paper, written by E. Gracheva, M. Toshkhodzhaeva, O. Rahimov, S. Dadabaev, D. Mirkhalikova, S. Ilyashenko and V. Frolov, develops methods for analyzing the functional reliability of the power system and proposes reliability indicators and a criterion for the efficiency of the operation of the $110 \mathrm{kV}$ overhead transmission line. The authors argue that when the relief, climate, and operational factors change, the level of reliability is $95 \%$.

The eleventh paper, written by 0. Zaborovskaia, E. Sharafanova, and L. Maksanova, develops a scenario forecast of the volume and rate of recovery in tourist flows, which have experienced a catastrophic decline due to restrictions imposed by the COVID-19 threat. The authors argue that forecasting results can underpin the development of options for regional programs to support the tourism industry, which will increase the efficiency of spending.

The next paper, written by A. Borovkov, M. Bolsunovskaya, A. Gintciak, and T.J. Kudryavtseva, proposes a method for assessing the consequences of partial regional isolation in the context of epidemiological and economic sectors using simulation modeling and system dynamics. The authors argue that the Susceptible-Infected-Recovered model can be used to estimate the potential mortality in the region, the burden on the healthcare system, and the economic damage as a result of the pandemic.

The thirteenth paper, written by T. Kudryavtseva and A. Skhvediani, evaluates the effectiveness of investments in robotic technologies for biological plant protection in greenhouse enterprises using a financial model, which is supplemented by the technical and economic parameters of digital technologies. The authors argue that the introduction of robotic biological plant protection technology improves the profitability of the agricultural enterprise; they find that this investment pays off in two years. 
The fourteenth paper, written by D.S. Balzamov, I.G. Akhmetova, V.V. Bronskaya, O.S. Kharitonova, and E.Yu. Balzamova, investigates the high-temperature section of dehydrogenation of isoamylenes into isoprene, the production of which relates to largecapacity energy-consuming industries. The authors argue that the proposed schemes offer the industry the opportunity to save a significant amount of heat energy (i.e., 58730.25 $\mathrm{kW} / \mathrm{h}$ ) in the production of isoprene and thus achieve a reduction in its cost.

The next paper, written by N. Politaeva, E. Taranovskaya, L. Mukhametova, S. Ilyashenko, I. Atamanyuk, A.A. Rafat, and C. Pfeifer, investigates the capacity of heat-treated sorbent cotton fibers (CFs) and low-temperature graphite intercalation compounds (LTGICs) to improve the efficiency of wastewater purification from heavy metals and petroleum compounds. The authors argue that the thermal treatment of CFs resulted in increased numbers of micropores and mesopores, indicating a high sorption capacity for petroleum products in wastewater $(A=11.5 \mathrm{~g} / \mathrm{g})$ with an efficiency score of $90 \%$.

The sixteenth paper, written by L. Voropai, O. Kuznetsova, A. Sinitsyn, O. Yukhtarova, I. Akhmetova, I. Atamanyuk, and S. Ilyashenko, presents the production stages according to the new technology and establishes the impact of chemical composition on heat-insulating materials' (HIMs) performance characteristics. The authors argue that replacing gypsum with quicklime while excluding sawdust and a three-component polymer from the composite helped simplify the technology for obtaining HIMs while improving HIM characteristics.

The last paper, written by J.V. Vankov, R.R. Rotach, S.V. Laptev, S.G. Ziganshin, and O.V. Afanaseva, proposes a steam screw-rotor machine (SSRM) to improve the energy and economic efficiency of chemical enterprises. The authors argue that installation of an SSRM instead of a pressure reduction and de-superheating station leads to a reduction of the exergy losses of the system.

We hope that this edition of IJTech conveys some new insights into the way we conduct our research. We are pleased to accept and respond to any comment or inquiry you may have on the direction and content of IJTech, and we invite you to join us in this venture by sending your work for consideration.

With the warmest regards from Jakarta,

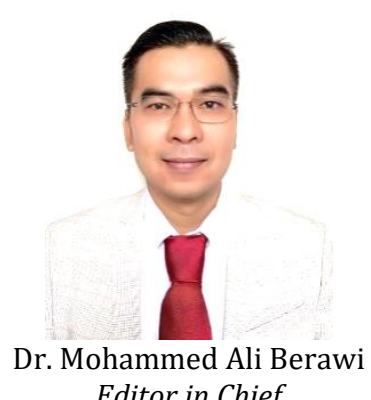
Editor in Chief

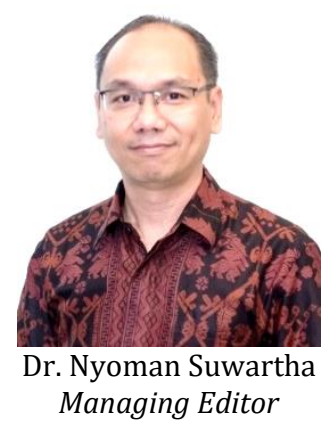

Managing Editor
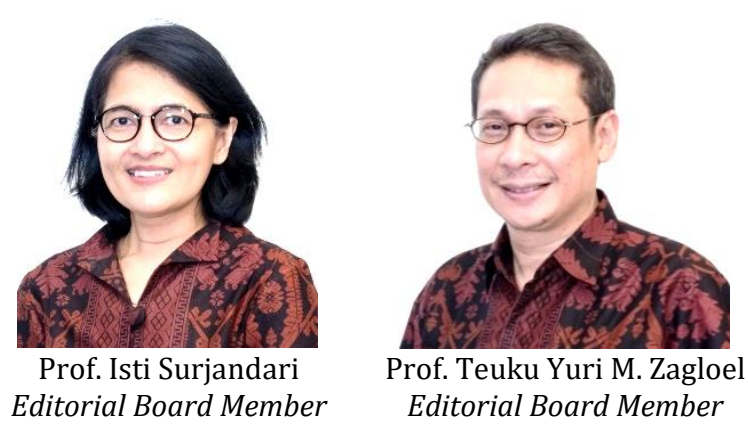


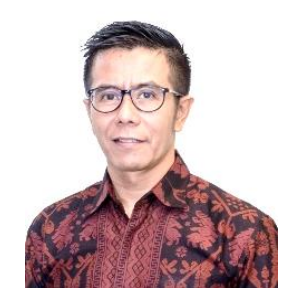

Dr. Muhamad Asvial Editorial Board Member

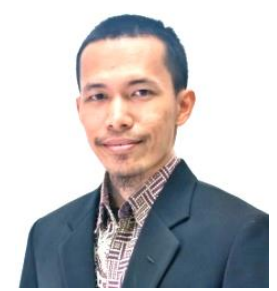

Dr. Ruki Harwahyu Editorial Board Member

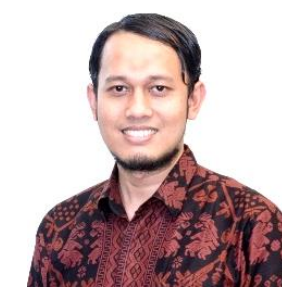

Dr. Muhammad Suryanegara Editorial Board Member

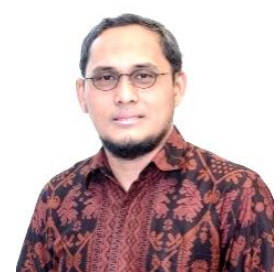

Dr. Eko Adhi Setiawan Editorial Board Member

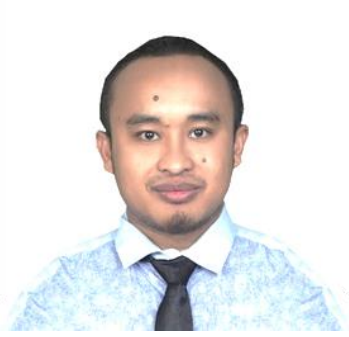

Dr. Imam Jauhari Maknun Editorial Board Member

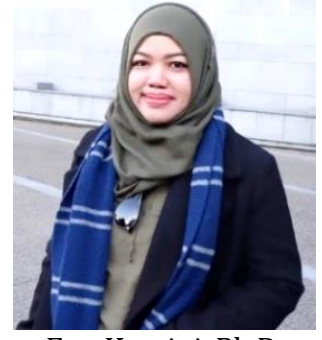

Eny Kusrini, Ph.D Editorial Board Member

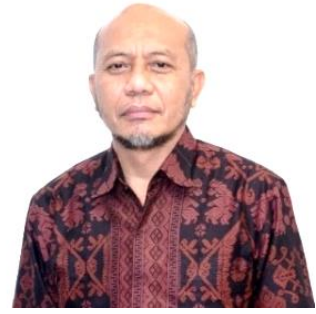

Prof. Sutrasno Kartohardjono Editorial Board Member

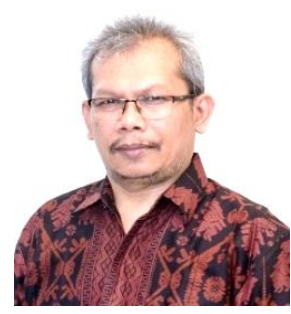

Dr. Nofrijon Sofyan Editorial Board Member

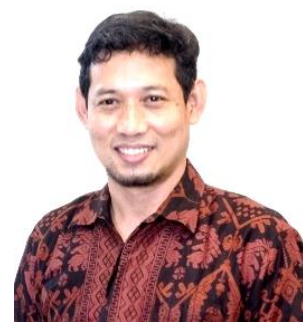

Prof. Akhmad Herman Yuwono Editorial Board Member

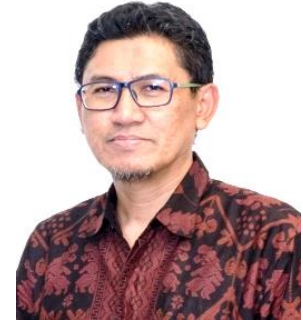

Dr. Sri Harjanto Editorial Board Member

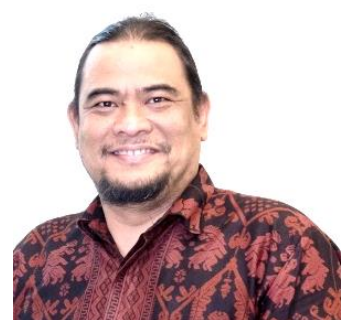

Prof. Nandy Putra Editorial Board Member

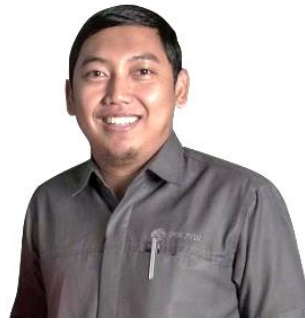

Dr. Muhammad Arif Budiyanto Editorial Board Member

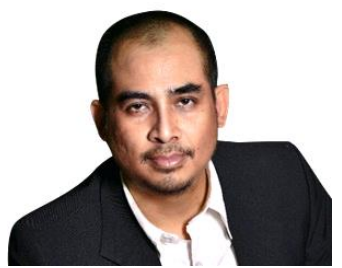

Dr. Yudan Whulanza

Editorial Board Member 